\title{
Politics and Research of Immigration: Implications for Counseling and Psychological Scholarship and Action
}

\author{
Oksana Yakushko \\ Pacifica Graduate Institute \\ Melissa L. Morgan Consoli \\ University of California Santa Barbara
}

\begin{abstract}
Research about and with recent immigrants has expanded within psychology, counseling, and related fields. Such research has a potential to contribute significantly toward social action through affecting cultural understanding and public policies. However, counseling and psychology professionals and researchers often lack understanding of historical and current trends affecting this research. Thus, in this article we discuss the broader contextual influences on the scholarly focus on immigration within the psychological literature, reviewing the issues and debates, both historical and current, that dominate scholarly discussions regarding constructs related to immigration. Specifically, we focus on reviewing divergent perspectives on acculturation, transnationalism and immigrant identity, immigrant mental health issues, measurement strategies, and attitudes toward immigrants. Lastly, the article highlights the intersection of politics and research in immigration scholarship within counseling and psychology. Specific suggestions for social action resulting from this knowledge are presented.
\end{abstract}

Keywords: immigration; research; social Justice; multiculturalism.

\section{Introduction}

Conducting research which focuses on the experiences of underrepresented populations has been viewed as one of the primary ways that psychologists and counselors, especially within academic settings, engage in social justice-focused action (Pope-Davis, Coleman, Liu, \& Toporek, 2003; Vera \& Speight, 2003). On the other hand, psychological research is bound by social and political contextual constraints, often serving to maintain the societal status quo and reinforce prejudicial social structures that further oppress those who are marginalized (Fox, Prilleltensky, \& Austin, 2009; Watkins, 2011). This maintenance of the "status quo" within psychology has perhaps prevented the field from focusing on the needs of marginalized populations such as immigrants or from addressing lager contextual forces affecting these individuals and communities, specifically through research. This manuscript therefore highlights the historical and social factors influencing such research as well as the need for social action 
and justice-focused scholarship in this area. Specifically, in this contribution we highlight ways in which research involving recent immigrants has been responsive to and responsible for social action as well as critique this research for often failing to address its assumptions.

Although immigrants who are racial and ethnic minorities have been included in multicultural psychology literature (e.g., Ponterotto, Casas, Suzuki, \& Alexander, 2010; Sue \& Sue, 1999), systematic writings regarding the distinct social justice needs of this population are relatively recent (e.g., Yakushko, 2009). The number of foreign-born individuals in the United States increased by $100 \%$ between the 1970 s and 2000 s, and is predicted to continue to dramatically increase in the next decades related to socio-political factors such as increasing economic and environmental inequality between the "developed" and the "developing" worlds, as well as military conflicts (Day, 2011; Marsella \& Ring, 2003). Thus, it is critical that mental health professionals and scholars understand the significance of immigration to their work within the larger cultural milieu.

Research by psychology and counseling scholars has primarily addressed immigrants as racially diverse individuals in the context of U.S. race relations (Arredondo, 1998; Atkinson \& Schein, 1986; Casas, 1982; Helms, 1984; Leong, 1986; Parham \& Helms, 1981; Sue, 1978). Multicultural foci in counseling and psychology have emphasized competent and culturally relevant research and clinical work with U.S. ethnic and racial minorities, whether or not they were native or foreign born. However, the experiences of migration as well as treatment based on immigrant rather than racial status has begun to receive greater scholarly attention only recently (Yakushko, 2009).

Awareness of the need for an immigration-specific focus within psychology and counseling is also related to the commitment to global and international awareness in the field (Gerstein et al., 2009; Heppner et al., 2000). It should be pointed out however, that this international focus encompasses immigrants, but does not focus on them specifically. Lack of awareness concerning both the contexts and trends within research on immigration may result in a lack of social justice action or in the perpetuation of invisibility and marginalization of immigrants and their distinct needs and perspectives (Fox, Prilleltensky, \& Austin, 2009; Lorenz \& Watkins, 2010; Watkins, 2011).

\section{Political and Historical Influences of Immigration Research}

Immigration continues to be a hotly debated political issue as well as an academic area marked with scholarly disagreements and critiques (Foner, Rumbaut, \& Gold, 2000). Historically, political climates have had a significant influence on migration research across varied disciplines (Gabaccia, 2006). For example, early research on immigration focused on population control and cultural assimilation (Gabaccia), while the current political zeitgeist in the U.S. is marked by a significant polarization of views on immigration (Nakaya, 2010; Watkins, 2007). Specifically, the rise in the number of immigrants has garnered sustained and primarily negative reactions from both native-born U.S. citizens and their political representatives (Yakushko, 2009), many of whom believe that immigrants are a social burden because they are more likely to be involved in criminal activities. Additionally, it is often believed that immigrants usurp jobs needed for native-born individuals and leech social resources without paying taxes (Buckler, Swatt, \& Salinas, 2009; Lee \& Ottati, 2002). These beliefs, increased by the 9/11 terrorist 
attacks, have led to higher border security, increased surveillance of immigrants, and stricter immigration policies. In addition to these changes, the U.S. Immigration and Customs Enforcement (ICE) agency was created in 2003 to focus on enforcing immigration laws such as locating, imprisoning, and deporting undocumented immigrants (Buckler et al.). Despite very recent change in the political emphasis on "immigration reform," the primary national focus has been on increasing the flow of highly skilled and educated immigrants (i.e., the "brain drain") and on "securing the borders" rather than on economic justice and protection for the majority of immigrants (National Network of Immigrant and Refugee Rights, 2014). Undoubtedly, these broader cultural perspectives are reflected in research. Apostolidis (2008) contended that immigrant research often reflects implicit assumptions imbedded within the larger society that continues to view immigrants and migration as a "problem" with an overarching emphasis on immigrant's adaptation to receiving the country's norms and perceptions. Furthermore, SuarezOrozco and Carhill (2008) pointed out that much of the scholarship focuses on immigrant individuals without considering the impact of their families and communities on their individual experience. They also suggested that current research tends to pathologize some groups of immigrants while elevating other groups to a status of "model" minorities, specifically those who have appeared to adapt to normative values of the host society. Additionally, the scholarship often reflects a static perception of what constitutes migration. Transnationalism rather than one-way immigration appears to best describe the experiences of many individuals who cross the border for purposes of income generation without identifying wholly with either their host or home culture (see Portes, 2003).

Another challenge related to the cultural zeitgeist's influence on immigration research is that the preponderance of studies explore immigrants' experiences exclusively in the context of race relations. For example, Dovidio and Essess (2001) highlighted that extant studies specific to immigrants tend to reflect U.S. cultural and political emphases on Black versus White relations, which tends to exclude attention to other forms of cultural diversity such as social class, ethnicity, religion, and gender.

Lastly, globalization has had a significant influence on migration in general and immigration research specifically (Bhabha, 1994; Faist, 2000; Portes, 2001; Schiller, Basch \& Blanc, 1995; Vertovec, 1999). Scholars who critically examine the impact of globalization highlight that Western values and worldviews have a colonizing effect on individuals even prior to their relocation through global media and cultural influences (e.g., denigrating indigenous knowledge and practices). Such a focus on distinct uni-directional immigrant identity development is problematic (Bhabha, 1994).

Thus, the research with the immigrant population often focuses on discrete groupings of immigrants that appear to be defined by dominant political and cultural views (e.g., Mexican immigrants as representing all Latino or all immigrant individuals residing in the U.S.). The research also often reflects the determinations of what are well-functioning or adapted immigrants as defined by the host community rather than by examining the impact of continued oppressive, anti-immigrant rhetoric and influences of globalization such as transnationalism (Bhabha, 1994; Faist, 2000; Portes, 2001; Schiller et al., 1995; Vertovec, 1999).

Understanding how historical realities and political environments influence immigration research is essential for psychologists and counselors. This knowledge may guide them in critically examining assumptions in research and the contextual factors that shape it, specifically related 
to theories and trends in immigration scholarship. Moreover, this awareness can help scholars pay closer attention to the consequences of their investigations as well as possibilities for social action, both for participants and for the larger host community. In other words, such awareness can help lead to actions of social justice.

\section{Theories and Trends in Immigration Research}

Paralleling the evolving political debates on immigration, immigration research has been marked by contrasting theories and trends, which reflect perspectives that either attend to or ignore issues of social justice. Although immigration research touches on varied facets of the migration experience, we chose to emphasize those theories and scholarly foci that seem to be predominant in the counseling and psychological literature. Specifically, these areas feature concepts such as acculturation, immigrant identity, mental health functioning, instrumentation, and attitudes toward immigrants.

\section{Acculturation}

One of the most prevalent areas of research pertaining to immigrants is acculturation. The dominant definition of acculturation focuses on a process of adaptation by migrating individuals to a receiving culture (Chun, Balls Organista, \& Marin, 2003). The most common model of acculturation by Berry (1997) emphasized that immigrant individuals can choose one of four paths: to assimilate to the host culture, to reject it in favor of their own, to reject both the host and their own culture, thus becoming marginalized, or to become bicultural. Numerous studies have utilized this model in order to determine how modes of adaptation are related to psychosocial outcomes (see Chun et al. for review). Biculturalism is typically emphasized as the ideal mode of adaptation in contrast to the other three pathways (Bautista de Domanico et al., 1994; Ryder et al., 2000). Furthermore, many measures of acculturation, which integrate this perspective, have also been developed (see Matsudaira, 2006, for review).

This dominant acculturation model has been criticized on psychometric, contextual, and socialconstructionist grounds. Rudmin $(2003,2009)$ stated that it is impossible to compare individuals on an acculturation continuum (e.g., acculturation status may shift from context to context). Chirkov (2009) discussed that immigrants' acculturation is highly variable even within similar national origin groups because of numerous factors that influence the process of adaptation. Rothman, Pointkowsky, and van Randenborgh (2008) also suggested that this process is interactional in that political events, cultural shifts, and dominant discourse can influence the adaptation experienced by immigrant individuals in fluid, dynamic ways, and, in turn, these contexts are continually influenced by immigrants. Finally, current acculturation discourse has been challenged as racist because of the implicit requirement for immigrants to adapt to their host communities or being blamed for not doing so (Van Dijk, 1997). Power structures involved in dictating how acculturation should proceed are often not made visible: optimal acculturation is determined by the members of the host community and not by immigrants themselves (Edley \& Wetherell, 2001). Community Based Participatory Research, where the participant is a partner in designing the study and determining results, would serve this function well.

Acculturation studies themselves have also yielded contradictory results with immigrant populations. Integration or biculturalism has been found related to positive mental health 
outcomes (e.g., Chen, Bond, \& Benet-Martinez, 2008; David, Okazaki \& Saw, 2009), to higher subjective well-being (Bautista de Domanico et al., 1994; Ryder et al., 2000) and to better mental health functioning (Lang, Munoz, Bernal, \& Sorensen, 1982), especially for younger, first generation immigrants. At the same time, many studies have shown that higher levels of biculturalism are connected to lower mental health functioning such as increased substance use as well as higher rates of suicide and depression, especially among Latino/a immigrants (e.g., Lara, Gamboa, Kahramanian, Morales \& Bautista, 2005; Marin \& Posner, 1995; Unger et al., 2000). Thus, although results of studies appear contradictory and inconclusive, clinical and scholarly literature, as well as popular media sources, continue to focus primarily on biculturalism as the optimal mode of adaptation. This optimal view of acculturation ignores the multiple contextual influences and fluidity of identity related to adaptation, further pathologizing immigrants who may not fit the predetermined patterns of acculturation.

New models of acculturation have been proposed, such as the Interactive Acculturation Model (Bourhis et al., 1997), which suggests that in order to examine the acculturation of any given individual or immigrant community, scholars must attend to three factors: (1) the individuals' acculturative strategies, (2) the host society's acculturative expectations toward immigrants, and (3) the interactive outcomes of relations between immigrant and native-born communities. Abraido-Lanza (2006), writing from a public health research perspective, suggested that acculturation studies take into account that acculturation may be a proxy for other factors such as poverty or exposure to traumatic events prior to and after migration. Specifically, those immigrants who face such disadvantages may be at greater risk for struggling while adapting to a new culture and their adaptation strategies may serve as their coping mechanisms in dealing with the challenges of immigration.

Peidra and Engstrom (2009) utilized Segmented Assimilation theory (Portes \& Rumbaut, 2001; Portes \& Zhou, 1993), which seeks to explain differential cultural adaptation of immigrant parents and their children. They integrated their theory together with the ecologically based life model (Germain \& Gitterman, 1996) to suggest that immigrants' acculturation within families and communities is guided by multiple contextual factors that include spheres from intraindividual to societal. Schwartz, Unger, Zamboanga, and Szapocznik (2010) also proposed a framework for understanding acculturation that accounts for such factors as immigrants' ethnic backgrounds, their cultural similarities to the host community, and their experiences of discrimination. These authors place special emphasis on the context of receptivity as a key factor in acculturation processes.

Despite these proposed new models, the literature on immigrants continues to emphasize unidirectional, categorical acculturation processes. It is suggested that researchers could gain more awareness of alternative conceptualizations of acculturation to truly achieve socially just research results that can inform social action.

\section{Immigrant Identity}

Another area of research pertains to the individuals' perception of the nature of their immigration experience, which reflects dynamics of globalization. The term transnational identity emerged at the end of the 1990s in sociological and migration studies literature (Portes, Guarnizo, \& Landolt, 1999). Portes and colleagues defined transnationalism as a phenomenon 
explaining the experiences of individuals, groups, and organizations as occurring across borders and within multiple cultural and national spaces rather than taking place within a determined nation-state. Research has shown that many immigrant individuals families do not perceive their migration as uni-directional (i.e., from home to host culture) but engage in continued back and forth movement between borders as well as engaging in similar negotiations between their own and receiving cultural traditions (Faist, 2000; Portes, 2001; Schiller et al., 1995; Vertovec, 1999). Transnationalism as a scholarly concept has been marginal within psychological and counseling scholarly discourse. This concept problematizes a static perception of immigrant identity and experience, including how global businesses and mobile technologies transform notions of how individuals cross cultural and national borders. A research agenda that emphasizes social justice and social action must attend to the more dynamic ways in which migration occurs, empowering immigrant individuals and communities who seek to deal with shifting economic and political realities.

Related to transnationalism is the hybrid nature of individual and group identities, first highlighted in sociology and critical cultural studies (Ashcroft, Griffiths, \& Tiffin, 1995; Bhabha, 1994; Marotta, 2008; Pieterse, 2009). Hybridity implies that immigrants continually negotiate and adapt their views of themselves in different contexts as well as create new forms of selfidentity, which selectively incorporate and rejects elements of both their home and host culture. In addition, globalization further diffuses supposed cultural boundaries and worldviews that have been viewed as defining identity (e.g., sexuality, religion) (Marotta, 2008).

Bhabha (1994) suggested that Western values have long held colonizing influences on individual identities and the perceptions of what cultural practices are valuable to imitate for communities around the world. Although such influence was spread literally through imperial take over of nations and states, introducing Western values as superior to indigenous knowledge, these effects have remained significant in how individuals outside the West shape their identities (Bhabha, 1994). Recent technological advances, have further contributed to permeability of cultural borders, appearing to reinforce the notions that Western values and practices are superior and to be imitated, thus affecting identity formation for non-Western individuals from childhood to adulthood, regardless of whether they choose to migrate or not (Rigoni, 2012).

Attending to the colonizing influences of Western values in research is difficult because of their implicit, unconscious nature. Liberation theorists suggest that any "work," including research with communities that experienced such influences, must include processes of conscientização or consciousness raising (Freire, 1972, 1998). For example, participant action, liberationoriented research with indigenous communities shows that individuals in these communities identify primarily with the concepts of "nomadic" and "hybrid" identities rather than fixed perceptions of who they are (Watkins, 2012). Therefore, the concepts of transnationalism and hybrid identity stand in opposition to the majority of immigrant research conducted within U.S. psychology, leaving underexplored factors which could more accurately characterize immigrants' experiences and lead to more social action and justice. 


\section{Immigrant Mental Health}

Undoubtedly, one of the main emphases of immigration research by counseling and psychology scholars has been on the mental health functioning and well-being of immigrants (e.g., Fong, 2003; Ponterotto et al., 2009; Pumariega, Rothe, \& Pumariega, 2005; Swinnen \& Selten, 2007). This literature typically highlights that immigrants tend to experience tremendous amounts of stress and trauma both prior to and after migration, and that these factors lead to psychological difficulties (Fong, 2003). Published scholarship and conference presentations reflect an overall assumption that, in contrast to native-born populations, immigrants are at high risk for being diagnosed with mental health disorders (Suarez-Orozco \& Carhill, 2001).

However, recent epidemiological studies both in the U.S. and Canada show that during initial years post migration immigrants show lower levels of both mental and physical health disorders than native-born populations (e.g., De Maio, 2010; Takeuchi, Alegria, Jackson, \& Williams, 2007). De Maio, who conducted a meta-analysis and a review of studies on this topic, indicated that the mental health functioning of immigrants appears to decline within two to ten years of their relocation, and that contextual factors, such as discrimination, appear to be among the best predictors for experiencing psychological distress. In addition, mental health outcomes worsen from first to second generation immigrants (i.e., from those who were born outside the U.S. to their children born in the U.S.), with an increase in substance abuse, suicides, and eating disorders (Miller \& Pumariega, 2001; Szapocznik \& Kurtines, 1989). These findings have been termed the "Immigrant Paradox" (Baker, 1996; Bender \& Castro, 2000; Sam, Vedder, Ward \& Horenczyk, 2006).

Rather than focusing on studies regarding pathologies experienced by immigrants and their subsequent generations, it may be vital to study reasons why immigration is damaging to individuals' well-being as well as how they can remain resilient in face of mounting negative pressures on their functioning. In addition, the research should place the causes of such pathologies not within immigrant individuals and communities but rather on external factors, such as discrimination, that appear to be at the root of declining mental health. Social action focused and social justice informed research with immigrants could focus on highlighting these contextual factors, contributing to their amelioration, and on helping immigrant communities build healthy and indigenous forms of resistance and resilience.

\section{Measurement Issues}

Measures developed to assess immigrants seem to have proliferated in the past few decades, mirroring the Western scholarly emphasis on quantitative approaches to both research and clinical practice. Taras (2009) catalogued 63 instruments that measure acculturation, either among immigrants in general or specific immigrant ethnic groups in particular. In addition to scales measuring acculturation, scholars have developed instruments that aid in the assessment of symptoms or experiences unique to immigrant groups. Among these measures is, for example, the Harvard Trauma Questionnaire (Mollica et al., 1992), which can be used to assess exposure to traumatic events and post-traumatic symptoms among refugees and immigrants.

One of the main critiques of these measures is that, although they were created to address experiences of a single immigrant community in a specific context (i.e., urban immigrants, 
refugees), they are frequently utilized in studies with other communities. Moreover, even those instruments that were developed for specific ethnic groups often lack attention to within group diversity and cultural variations (Cabassa, 2003; Chun, et al., 2003).

Even stronger critiques exist concerning the utilization of instruments developed for nonimmigrant populations in studies with immigrants (see Fabri, 2008; Suzuki \& Ponterotto, 2008). Similar to issues in research with native born American ethnic minorities, significant limitations for using such assessment instruments have been found regarding the use of terms, sampling, validity, procedures, and interpretations of data (Okazaki \& Sue, 1995). Furthermore, van der Vijver and Tanzer (2004) showed that in any cross-cultural assessment it is important to attend to the significance of bias and equivalence. These authors proposed that bias can be related to the construct (e.g., "mental disorder" vs. spiritual malaise), the method or administration (e.g., structured assessments vs. unstructured narratives), and the item selection (e.g., inclusion of Western versus indigenous assumptions regarding individual, interpersonal, and social functioning). They further discussed that equivalence challenges arise in creating comparisons between cultural groups (e.g., native born ethnic minorities vs. immigrant ethnic minorities).

Nevertheless, multiple studies about immigrant functioning utilize quantitative methods, purporting to rely on psychometrically valid and reliable measures. For socially just research to occur, it is important that researchers attend to these difficulties when devising investigations of immigrants' experiences. Furthermore, if assessments are to be conducted, attention can be given to creating instruments that attend to constructs, methods of administration, and item selection that are derived from immigrants themselves.

\section{Attitudes Toward Immigrants}

Another area of study in immigration that entails cultural and political debates focuses on negative attitudes toward immigrants. Yakushko (2009) defined xenophobia as "a form of attitudinal, affective, and behavioral prejudice toward immigrants and those perceived as foreign" (p. 81). Although prevalent in the U.S. and around the globe, xenophobia has not been an active area of research by U.S. psychology and counseling scholars, possibly because interethnic relations in the U.S. have been viewed through the lens of racial inequality (see Yakushko (2009) for review of xenophobia and racism). Nevertheless, when discussing attitudes toward recent immigrants, scholars continue to assess how "realistic" or "reality-based" the attitudes appear.

Thus, unlike other forms of prejudice, anti-immigrant discourse frequently focuses on discussion of its legitimacy (Fry, 2001). Questions such as "should the needs and rights of the host country or the needs and the rights of its migrants be seen as primary?" and "are selective immigration policies discriminatory?" are common in both the popular and scholarly debates (e.g., LeMay, 2004; Mills, 1994). Indeed, anti-immigrant sentiments are frequently accepted as justifiable because they are seen as based on the realistic concern of the host community (Fry). Two other general threads in understanding attitudes toward immigrants that dominate the scholarly debates include: theories related to social order that attempt to explain anti-immigrant attitudes, and how social contact influences these attitudes. Among these theories are the Realistic Group Conflict theory (Sherif, Harvey, White, Hood, \& Sherif, 1961), which suggests that competition for limited resources inevitably leads to a conflict between groups and the 
Integrated Theory of Prejudice (Stephan \& Stephan, 2000; Stephan, Ybarra, \& Bachman, 1999), which expands on theory of realistic threat and adds to it the experience of intergroup anxiety and stereotyping. However, scholars have continually shown that "threat" experienced by host community from immigrants is not based in "reality" (Cashdan, 2001; Sorenson \& Krahn, 1996). For example, Watkins (2011) pointed out that the post 9-11 focus on terrorists and terrorism continues to frame cultural discourse concerning the apparent dangers of immigrants, further criminalizing migration and migrants.

Although such theories may explain why host communities engage in discriminatory and exclusionary practices toward immigrants, it may be important for scholars to also engage with theoretical frameworks that question such social assumptions regarding oppression rather than reinforce them. For example, liberation and critical approaches, including in counseling and psychology, problematize hierarchies and make visible the structure of power within societies (Fox \& Prilleltensky, 1999; Freire, 1998). In addition, these theoretical approaches specifically call for social actions that address biases and inequalities.

\section{Social Action Research in Immigration Research}

In prior sections of this manuscript we have sought to elucidate how past and present historical beliefs and assumptions have shaped the context of immigration research. In addition, we have discussed areas of immigration research in counseling and psychology that appear to be prevalent as well as offered suggestions on how the study of these very same areas could shift toward a more social justice focused agenda. However, we also want to highlight that psychology and counseling scholarship has not remained silent regarding the glaring challenges faced by immigrant communities.

One such example is related to the increased imprisonment and deportation of unauthorized immigrants. Between the late 1990s and mid-2010s, detention and deportation of undocumented immigrants, including children, asylum seekers, and immigrant torture survivors, has more than tripled (Brané \& Lundholm, 2007; Chelgren, 2011). Legal scholars and human rights activists have decried such detention and deportation as violating international human rights laws (Chelgren; Rabin, 2008). These practices have been shown to have significant negative influences on immigrant individuals, families, and communities (Gonzales \& Morgan Consoli, 2013; Orozco, Consoli, Morgan Consoli \& Valencia, unpublished manuscript). In addition, the long term emotional impact of uncertainty and fear among undocumented immigrants has also been documented (Cavazos-Rehg, Zayas, \& Spitznagel, 2007; Rabin, 2008).

Continued criminalization of immigration that paints immigrants and migration as a "security threat" as well as broader powers of authorities to question and detain immigrants (such as Arizona SB 1070 law), undoubtedly have an impact on the well-being and mental health functioning of immigrant individuals (Furman et al., 2012). However, research related to psycho-social aspects of imprisonment and deportation remains limited, and the experiences of individuals detained and relocated continues to be culturally invisible (Rabin, 2008). Watkins (2009) discusses strategies that psychologists and counselors could take in seeking justice for immigrants who are imprisoned and deported without upholding their human rights and dignity. 
In addition to attending to issues that have profound negative effects on immigrant communities and individuals, psychology and counseling scholars seeking to engage in socially just scholarship with immigrants may need to explore methodologies which are alternative to those traditionally taught in U.S. graduate schools. Specifically, many methodologists who focus on research with marginalized populations emphasize the importance of qualitative and participatory approaches (e.g., Ægisdotter, Gerstein, \& Cinarbus, 2008; Flores et al., 2011; Ojeda, Flores, Meza, \& Morales, 2011). Iosifides (2003), a quantitative scholar, who sought to study undocumented immigrants in the context of Greece, discussed how quantitative scholarship may be disadvantageous because of the justifiable reluctance of undocumented individuals to provide any written information and because such research cannot address dynamic structural or individual aspects of their experiences. Ojeda and colleagues (2011) also detailed how recruitment of immigrant participants, attention to context and language, the creation of collaborative community research teams, and attention to the relationship between participants and researchers are best addressed through qualitative methods.

Qualitative and mixed methods studies can also be conducted with an emphasis on community involvement and empowerment. One successful mixed methods example of such an approach was a study utilizing Community Based Participatory Research with immigrant women in Rochester, New York (Wieland et al., 2012). In this program, immigrant women collaboratively designed a nutrition and exercise program with researchers. In addition, scholars such as Watkins (2009) provide examples of qualitative participatory and community based work that is focused on restorative justice and dialogue, specifically within prisons and the criminal justice system. Such research methods benefit communities through self-empowerment in the design and implementation of the study and dissemination of results. Specifically anchored in community dialogue (Israel, Shulz, Parker, \& Becker, 1998), insights and abilities of community members are used to discover and address issues that they themselves identify as salient (Knightbridge, King, \& Rolfe, 2006; Minore, Boone, Katt, Kinch, \& Birch, 2004) for the purposes of creating positive social change from which the community will benefit (Fals-Borda \& Rahman, 1991). For example, in the CBPR program mentioned above, community women not only benefitted from their direct participation in the nutrition and exercise program, but also in the self-empowerment that occurred with their own development of the program that benefitted their community, based on their own knowledge and experiences.

To achieve such positive change, particularly with social policy issues, social action research has been recommended. Historically, psychologists have been told not to mix politics and research, however, we are suggesting as a best practice, as have other special action researchers, that it is just such a mixture, putting our knowledge of research to use to affect social change (Brydon-Miller, 1997), that is called for with immigration research.

As we have suggested, such social action through research on immigration is more possible when it is informed by a critical understanding of the historical and current debates and theories within the scholarship on migration. Critical approaches may confront such issues directly within the framework of the study by acknowledging the continued discriminatory and hostile environments in which immigrants live and make meaning of their own experiences (Fox \& Prilleltensky, 1999). Moreover, Watkins and Shulman (2003) encouraged that principles of liberation psychology, such as processes of community consciousness raising, envisioning of the future, and self-empowerment, should be utilized in research work with any community that experienced marginalization such as many immigrant communities. 


\section{Conclusion: Research and Politics}

Research in psychology, including research on immigration, does not stand outside of political discourse. Psychological research has been critiqued as not only unresponsive to sociopolitical struggles but also responsible for maintaining the status quo of political agendas and cultural prejudices (e.g., Danziger, 1990; Fox, 1985, 1991, 1993; Fox, Prilleltensky, \& Austin, 2009). Despite recent introduction of "immigration reforms," current U.S. political and cultural discourse is characterized by tremendous anti-immigrant sentiment, which has direct and indirect negative impact on millions of immigrant women, men, and children in the U.S. (Morgan Consoli \& Gonzales, 2009; Yakushko, 2009). Although considerable efforts have been made to bring a focus on immigration to the forefront of psychological research and practice (e.g., Vasquez's APA presidential initiatives and task force related to immigration in 2009), immigration research is not systematic, continues to focus on immigrant's assimilation into the host community, and does not seek to actively address injustices faced by immigrants (Zarate \& Quezarda, 2011). Suarez-Orozco and Carhill (2008) showed that published investigations on immigrants tend to either idealize or pathologize them, further individualizing their experiences rather than placing them within ecological systems. Similarly, Willis (2010) highlighted that in parallel to political views of immigrants and immigration, research on immigration appears to focus on how to facilitate immigrants' successful adjustment to U.S. norms and how to help them become skilled as U.S. employees rather than supporting individuals in pursuit of their own goals and dreams.

Vera and Speight (2003) suggested that psychologists' and counselors' research agendas must actively seek to address social injustices. Immigration research offers an opportunity to actively engage in social action research addressing social disparities and prejudices related to immigrants (Watkins, 2009; Yakushko, 2009). In addition, it allows scholars to conduct collaborative, interdisciplinary, and cross-cultural research, thus expanding not only our knowledge about immigration experiences, but increasing our repertoire of scholarly methods and programs. Specifically, community based, action-oriented research agendas may best address the complex and dynamic nature of immigrant experiences while also seeking to empower participants as co-researchers and co-actors in scholarly work. Indeed, we would like to suggest that such approaches be considered best practices among counseling and psychological researchers. A better understanding of current theories, debates, and trends in research with immigrant communities is essential in creating such vibrant and socially responsible scholarship, as well as aiding psychology and counseling scholars in construing their scholarship within an emancipatory and ecologically sound framework.

\section{Contact Information:}

Oksana Yakushko

Pacifica Graduate Institute

249 Lambert Rd.

Carpinteria, CA 93013

Email: oyakushko@pacifica.edu 


\section{References}

Abraído-Lanza, A. F., Armbrister, A. N., Flórez, K. R., \& Aguirre, A. N. (2006). Toward a theorydriven model of acculturation in public health research. American Journal of Public Health, 96(8), 13-42.

Ægisdottir, S., Gerstein, L.H., \& Cinarbus, D.C. (2008). Methodological issues in cross-cultural counseling research: Equivalence, bias, and translations. The Counseling Psychologist, 36, 188-219. http://dx.doi.org/10.1177/0011000007305384

Ajrouch, K.J. (2005). Arab-American immigrant elders' views about social support. Aging and Society, 25, 655-673.

Al-Johar, D. (2005). Muslim marriages in America: Reflecting new identities. The Muslim World, 95, 557-574. doi: 10.1111/j.1478-1913.2005.00111.x.

American Psychological Association (2010). Resilience and recovery after war: Refugee children and families in the United States. Washington, DC: Author. Retrieved from: http://www.apa.org/pi/families/refugees.aspx

American Psychological Association (2011). Crossroads: The psychology of immigration in the new century. Report of the 2011 Presidential Taskforce on Immigration. Washington, D.C. Retrieved from http://www.apa.org/topics/immigration/report.aspx.

Apostolidis, P. (2008). Feminist theory, immigrant workers' stories, and counterhegemony in the United States today. Signs, 33(3), 545-568.

Aredondo, P. (1998). Integrating multicultural counseling competencies and universal helping conditions in culture-specific contexts. The Counseling Psychologist, 26, 592-601. http://dx.doi.org/10.1177/0011000098264003

Ashcroft, B., Griffiths, G., \& Tiffin, H. (2001). Key concepts in post-colonial studies. New York: Routledge.

Atkinson, D. R., Furlong, M. J., \& Poston, W. C. (1986). Afro-American preferences for counselor characteristics. Journal of Counseling Psychology, 33(3), 326. http://dx.doi.org/10.1037//0022-0167.33.3.326

Bacon, D. (2012). Displaced, unequal and criminalized: The fight for the rights of migrants in the United States. Report for the Rosa Luxemburg Foundation. Retrieved from http://www.cipamericas.org/archives/6080

Baker, S. G. (1996). Demographic trends in the Chicana/ population: Policy implications for the $21^{\text {st }}$ century. In D. Maciel and I. Ortiz, (Eds.) Chicanas/Chicanos at the Crossroads: Social, Economic, and Political Change, (pp. 5-24). Tucson: University of Arizona Press. 
Brané, M., \& Lundholm, C. (2007). Human rights behind bars: Advancing the rights of immigration detainees in the United States through human rights frameworks. Georgetown Immigration Law Journal, 22, 109-179.

Bender, D. \& Castro, D. (2000). Explaining the birth weight paradox: Latina immigrants' perceptions of resilience and risk. Journal of Immigrant Health, 2(3), 155-173.

Berry, J. W. (1997). Immigration, acculturation, and adaptation. Applied psychology, 46(1), 534. http://dx.doi.org/10.1111/j.1464-0597.1997.tb01087.x

Berry, J. W. (2003). Conceptual approaches to acculturation. In K. M. Chun, P. B. Organista, \& G. Marín (Eds.), Acculturation: Advances in theory, measurement and applied research (pp. 17-37). Washington, D.C.: American Psychological Association.

Bhabha, H. K. (1994). The location of culture. New York: Routledge.

Bhatia, S., \& Ram, A. (2001). Rethinking "acculturation" in relation to diasporic cultures and postcolonial identities. Human Development, 44(1), 1-18.

Birman, D. (2005). Ethical issues in research with immigrants and refugees. In J.E. Trimble \& C.B. Fisher (Eds.) The handbook of ethical research with ethnocultural populations \& communities (pp. 155-177). Thousand Oaks, CA: Publications.

Bourhis, R. Y., Moïse, L. C., Perreault, S., \& Senecal, S. (1997). Towards an interactive acculturation model: A social psychological approach. International journal of psychology, 32(6), 369-386. http://dx.doi.org/10.1080/002075997400629

Bowskill, M., Lyons, E., \& Coyle, A. (2007). The rhetoric of acculturation: When integration means assimilation. British Journal of Social Psychology, 46, 793-813.

Bronfenbrenner, U., \& Morris, P. A. (2006). The bioecological model of human development. In W. Damon, \& R. M. Lerner (Eds.), Handbook of child psychology, theoretical models of human development (6th ed., Vol. 1, pp.993-1023). Hoboken, NJ: John Wiley \& Sons, Inc.

Bryceson, D. F., \& Vuorela, U. (Eds.) (2002). The transnational family: New European frontiers and global networks. New York, NY: Oxford University Press.

Brydon-Miller, M. (1997). Participatory action research: Psychology and social change. Journal of Social Issues, 53(4), 657-666. Retrieved from http://search.proquest.com/docview/619361086?accountid=14522

Cabassa, L. J. (2003). Measuring acculturation: Where we are and where we need to go. Hispanic Journal of Behavioral Sciences, 25(2), 127-146. http://dx.doi.org/10.1177/0739986303025002001

Casas, J. (1982). Counseling psychology in the marketplace: The status of ethnic minorities. The Counseling Psychologist, 37, 780-787. 
Cashdan, E. (2001). Ethnocentrism and xenophobia: A cross-cultural study. Current Anthropology, 42, 760-765. http://dx.doi.org/10.1086/323821

Cavazos-Rehg, P. A., Zayas, L. H., \& Spitznagel, E. L. (2007). Legal status, emotional well-being and subjective health status of Latino immigrants. Journal of the National Medical Association, 99(10), 1126.

Center for History and New Media. (n.d.). Zotero Quick Start Guide. Retrieved from http://zotero.org/support/quick_start_guide.

Chelgren, W. (2011). Preventive detention distorted: Why it is unconstitutional to detain immigrants without procedural protections. Loyola of Los Angeles Law Review, 44(4), 314.

Chen, S. X., Benet-Martínez, V., \& Harris Bond, M. (2008). Bicultural identity, bilingualism, and psychological adjustment in multicultural societies: Immigration-based and globalizationbased acculturation. Journal of Personality, 76(4), 803-838. http://dx.doi.org/10.1111/j.1467-6494.2008.00505.x

Chirkov, V. (2009). Critical psychology of acculturation: What do we study and how do we study it, when we investigate acculturation? International Journal of Intercultural Relations, $33(2), 94-105$.

Danziger, K. (1990). Constructing the subject: Historical origins of psychological research. New York: Cambridge University Press

David, E., Okazaki, S., \& Saw, A. (2009). Bicultural self-efficacy among college students: Initial scale development and mental health correlates. Journal of Counseling Psychology, 56(2), 211. http://dx.doi.org/10.1037/a0015419

Day, J.C. (2011). Population projections of the United States by Age, Sex, Race and Hispanic Origin, 1993 to 2050. Current Population Reports, P25-1004. Washington, DC: US Census Bureau.

De Maio, F. G., \& others. (2010). Immigration as pathogenic: a systematic review of the health of immigrants to Canada. International Journal for Equity In Health, 9(1), 27. http://dx.doi.org/10.1186/1475-9276-9-27

Díaz-Guerrero, R. (1995). Una aproximación científica a la etnopsicología. Revista Latinoamericana de Psicología, 27, (3), 359-389.

Dillon, S. (October 15, 2001). Mexican immigrants face new set of fears. The New York Times, Late Edition, Section A, page 14, column 1.

Dovidio, J. F., \& Esses, V. M. (2001). Immigrants and immigration: Advancing the psychological perspective. Journal of Social Issues, 57(3), 378-387. http://dx.doi.org/10.1111/00224537.00219 
Espenshade, T. J. (2000). Immigrants, Puerto Ricans, and the earnings of native Black males. In G. D. Jaynes (Ed.), Immigration and race: New challenges for American democracy. (pp. 125-142). New Haven, CT: Yale University Press.

Espino, R. \& Franz, M.M. (2002). Latino phenotypic discrimination revisited: The impact of skin color on occupational status. Social Science Quarterly, 83, 612-623. http://dx.doi.org/10.1111/1540-6237.00104

Fabri, M. (2008). Cultural adaptation and translation of assessment instruments for diverse populations. In L. A. Suzuki \& J. Ponterotto (Eds). Handbook of Multicultural Assessment: Clinical, Psychological, and Educational Applications, (p.195 - 219). San Francisco, CA: Jossey-Bess.

Faist, T. (2000). Transnationalization in international migration: implications for the study of citizenship and culture. Ethnic and Racial Studies, 23(2), 189-222. http://dx.doi.org/10.1080/014198700329024

Flores, L. Y., Hsieh, C., \& Chiao, H. (2011). Vocational psychology and assessment with immigrants in the United States: Future directions for training, research, and practice. Journal of Career Assessment, 19(3), 323-332. http://dx.doi.org/10.1177/1069072710395538

Foner, N., Rumbaut, R.G., \& Gold, S.J. (Eds.). (2000 ). Immigration research for a new century: An interdisciplinary perspective. New York, NY: Russell Sage Foundation.

Fong, R. (2003). Cultural competence with Asian Americans. In D. Lum (Ed.). Culturally competent practice: $A$ framework for understanding diverse groups and justice, $\left(2^{\text {nd }}\right.$ ed.), 261-281. Belmont, CA: Brooks/Cole.

Foster, R. P. (2001). When immigration is trauma: Guidelines for the individual and family clinician. American Journal of Orthopsychiatry, 71(2), 153-170. http://dx.doi.org/10.1037//0002-9432.71.2.153

Fox, D. R. (1985). Psychology, ideology, utopia, and the commons. American Psychologist, 40, 48-58. http://dx.doi.org/10.1037//0003-066X.40.1.48

Fox, D. R. (1991). Social science's limited role in resolving psycholegal social problems. Journal of Offender Rehabilitation, 17, 159-166. http://dx.doi.org/10.1300/J076v17n01_12

Fox, D. R. (1993). Psychological jurisprudence and radical social change. American Psychologist, 48, 234-241. http://dx.doi.org/10.1037//0003-066X.48.3.234

Fox, D., Prilleltensky, I., \& Austin, S. (2009). Critical psychology: An introduction. Sage Publications Ltd.

Freire, P. (1972). Pedagogy of the oppressed. New York, NY: Herder \& Herder.

Freire, P. (1998). The Paulo Freire Reader. New York, NY: Herder \& Herder. 
Fuentes, A. (2006, July 28). Immigration backlash goes local. USA Today, News, p. $13 a$.

Furman, R., Ackerman, A. R., Loya, M., Jones, S., \& Negi, N. (2012). The criminalization of immigration: Value conflicts for the social work profession. Journal of Sociology \& Social Welfare, 39(1), 169-185.

Gabaccia, D. R. (2006). Today's immigration policy debates: Do we need a little history? Migration Policy Institute (November 1). http://www. migrationinformation. org/Feature/print. cfm.

Germain, C. B., \& Gitterman, A. (1996). The life model of social work practice: Advances in theory \& practice. Columbia Univ Press.

Gerstein, L.H., Heppner, P.P., Ægisdottir, S., Leung, S.A., \& Norsworthy, K.L. (2009). International handbook of cross-cultural counseling: Cultural assumptions and practices worldwide. Thousand Oaks, CA: Sage Publications.

Gonzales, N. \& Morgan Consoli, M.L. (2013). The Aftermath of deportation: Effects on the family. Interamerican Journal of Psychology/Revista InterAmericana de Psicologia.

Helms, J. E. (1984). Toward a theoretical explanation of the effects of race on counseling: A black and white model. The Counseling Psychologist, 12(3-4), 153-165. http://dx.doi.org/10.1177/0011000084124013

Heppner, P., Casas, J. M., Carter, J., \& Stone, G. (2000). The maturation of counseling psychology: Multifaceted perspectives from 1978-1998. In S. Brown \& R. Lent (Eds.), Handbook of counseling psychology, third edition. New York: Wiley.

Hernandez, D. J. (2006). Immigration and diversity transforming America in the $21^{\text {st }}$ century. Opening plenary session conducted at the meeting of Expert Summit on Immigration of the American Psychological Association, San Antonio, TX.

Hovey, J. D. (2000). Acculturative stress, depression, and suicidal ideation in Mexican immigrants. Cultural Diversity and Ethnic Minority Psychology, 6, 134-151. http://dx.doi.org/10.1037/1099-9809.6.2.134

Hovey, J. D. \& Magana, C. J. (2003). Psychosocial predictors of anxiety among immigrant Mexican migrant farmworkers: Implications for prevention and treatment. Cultural Diversity and Ethnic Minority Psychology, 8, 274-289. http://dx.doi.org/10.1037//10999809.8.3.274

Hwa-Froelich, D. A., \& Westby, C. E. (2003). Considerations when working with interpreters. Communication Disorders Quarterly, 24, 78-85.

Iosifides, T. (2003). Qualitative migration research: Some new reflections six years later. The Qualitative Report, 8(3), 435-446. 
Jensen, L. A., Arnett, J. J., \& McKenzie, J. (2011). Globalization and cultural identity. In Handbook of identity theory and research (pp. 285-301). New York: Springer.

Jost, J. T., \& Banaji, M. R. (1994). The role of stereotyping in system-justification and he production of false consciousness. British Journal of Social Psychology, 33, 1-27.

Kim, C. J. (2000). The politics of Black-Korean conflict: Black power protest and the mobilization of racial communities in New York City. In G. D. Jaynes (Ed.), Immigration and race: New challenges for American democracy. (pp. 74-97). New Haven, CT: Yale University Press.

Lara, M., Gamboa, C., Kahramanian, M. I., Morales, L. S., \& Hayes Bautista, D. E. (2005). Acculturation and Latino health in the United States: a review of the literature and its sociopolitical context. Annual Review of Public Health, 26, 367-397. http://dx.doi.org/10.1146/annurev.publhealth.26.021304.144615

Larsen, L.J. (2004). The Foreign-Born Population in the United States: 2003. Washington, DC: US Census Bureau; 2003. Current Population Reports, P20-551.

Liebkind, K., \& Jasinskaja-Lahti, I. (2000a). The influence of experiences of discrimination on psychological stress: A comparison of seven immigrant groups. Journal of Community and Applied Social Psychology, 10, 1-16. http://dx.doi.org/10.1002/(SICI)10991298(200001/02)10:1\%3C1::AID-CASP521\%3E3.0.CO;2-5

Liebkind, K., \& Jasinskaja-Lahti, I. (2000b). Acculturation and psychological well-being among immigrant adolescents in Finland: A comparative study of adolescents from different cultural backgrounds. Journal of Adolescent Research, 15, 446-469. http://dx.doi.org/10.1177/0743558400154002

Liebkind, K., Jasinskaja-Lahti, I., \& Solheim, E. (2004). Cultural identity, perceived discrimination, and parental support as determinants of immigrants' school adjustment: Vietnamese youth in Finland. Journal of Adolescent Research, 19, 635-656.

Leong, F. T. (1986). Counseling and psychotherapy with Asian-Americans: Review of the literature. Journal of Counseling Psychology, 33(2), 196. http://dx.doi.org/10.1037//0022-0167.33.2.196

Lorenz, H. S., \& Watkins, M. (2002). Silenced knowings, forgotten springs: Paths to healing in the wake of colonialism. Radical Psychology: A Journal of Psychology, Politics, and Radicalism (online journal). http://www. radpsy. york. ca

Marín, G., Balls-Organista, P., \& Chung, K. (2001). Acculturation. Advances in Theory, Measurement, and Applied Research, 3-13.

Marin, G. \& Gamba, R.J. (1996). A new measurement of acculturation for Hispanics: The Bidimensional Acculturation Scale for Hispanics (BAS) Hispanic Journal of Behavioral Sciences, 18(3), 297-316. http://dx.doi.org/10.1177/07399863960183002 
Marotta, V. P. (2008). The hybrid self and the ambivalence of boundaries. Social Identities, 14(3), 295-312. http://dx.doi.org/10.1080/13504630802088052

Marsella, A. J., \& Ring, E. (2003). Human migration and immigration: An overview. In L. L. Adler \& U. P. Gielen (Eds.), Migration: Immigration and emigration in international perspective. (pp. 3-22). Westport, CT: Praeger.

Matsudaira, T. (2006). Measures of psychological acculturation: A review. Transcultural Psychiatry, 43(3), 462. http://dx.doi.org/10.1177/1363461506066989

Miller, M. N., \& Pumariega, A. J. (2001). Culture and eating disorders: A historical and crosscultural review. Psychiatry: Interpersonal and Biological Processes, 64(2), 93-110. http://dx.doi.org/10.1521/psyc.64.2.93.18621

Mollica, R. F., Caspi-Yavin, Y., Bollini, P., Truong, T., Tor, S., \& Lavelle, J. (1992). The Harvard Trauma Questionnaire: validating a cross-cultural instrument for measuring torture, trauma, and posttraumatic stress disorder in Indochinese refugees. The Journal of Nervous and Mental Disease, 180(2), 111-116. http://dx.doi.org/10.1097/00005053199202000-00008

Morgan Consoli, M. L., Consoli, A., Orozco, G., Gonzales, R.R., \& Vera, E. (2012). Barriers experienced by Mexican immigrants: Implications for educational achievement and mental health. Association of Mexican American Educators Journal, 6, $37-47$.

Morgan, M. L. \& Gonzales, R. R. (2009, Fall). Strength in the face of adversity: Latino/a resilience. Children, Youth and Families News, 4-6, American Psychological Association.

Munro, N. (2006). The immigrant numbers game. National Journal, 38, 5-7.

The National Network of Immigrant and Refugee Rights. (2014). The 10 principles for ensuring fair and humane immigration policy. Retrieved from http://www.nnirr.org/ nnirrorg/drupal/sites/default/files/10principlesfulltext.pdf on February 9, 2014.

Ojeda, L., Flores, L. Y., Meza, R. R., \& Morales, A. (2011). Culturally competent qualitative research with Latino immigrants. Hispanic Journal of Behavioral Sciences, 33(2), 184203. http://dx.doi.org/10.1177/0739986311402626

Okazaki, S., \& Sue, S. (1995). Methodological issues in assessment research with ethnic minorities. Psychological Assessment, 7(3), 367. http://dx.doi.org/10.1037//10403590.7.3.367

Ommundsen, R., Van der Veer, K., Yakushko, O., \& Ullenberg, P. (2013). Exploring the relationships between fear-based xenophobia, social contact, and perceptions of outgroup entitativity in Norway. Psychological Reports, 112(1), 109-124.

Orozco, G. L., Consoli, A., Morgan Consoli, M. L. \& Valencia, A. Children of deportees: Crises at home and in school. Unpublished manuscript. 
Parham, T. A., \& Helms, J. E. (1981). The influence of Black students' racial identity attitudes on preferences for counselor's race. Journal of Counseling Psychology, 28(3), 250.

Partida, Y. (2007). Addressing language barriers: Building response capacity for a changing nation. Journal of General Internal Medicine, 22(0), 347-349, doi: 10.1007/s11606-0070367-1.

Pernice, R. (1994). Methodological issues in research with refugees and immigrants. Professional Psychology: Research and Practice, 25, 207-213. http://dx.doi.org/10.1037//0735-7028.25.3.207

Pettigrew, T. F., \& Tropp, L. R. (2005). Allport's intergroup contact hypothesis: Its history and influence. In J. F. Dovidio, P. Glick, \& L. Rudman (Eds.), Reflecting on the nature of prejudice: Fifty years after Allport (pp. 262-277). Malden: Blackwell.

Pettigrew, T. F., \& Tropp, L. R. (2006). A meta-analytic test of intergroup contact theory. Journal of Personality and Social Psychology, 90(5), 751-783. http://dx.doi.org/10.1037/0022-3514.90.5.751

Pew Hispanic Center. (May 22, 2006). Modes of entry for the unauthorized migrant population. Retrieved from http://pewhispanic.org/files/factsheets/19.pdf.

Pew Research Center. (May 9, 2013). Most say immigration policy needs big changes. Retrieved from http://www.people-press.org/2013/05/09/most-say-immigration-policy-needs-bigchanges/2/.

Piedra, L. M., \& Engstrom, D. W. (2009). Segmented assimilation theory and the life model: An integrated approach to understanding immigrants and their children. Social Work, 54(3), 270-277. http://dx.doi.org/10.1093/sw/54.3.270

Pieterse, J. N. (2009). Globalization and culture: Global mélange. New York: Rowman \& Littlefield Publishers.

Pinto, R.M. (2002). Social work values, welfare reform and immigrant citizenship conflicts. Families in Society, 83, 85-92. http://dx.doi.org/10.1606/1044-3894.45

Ponterotto, J.G., Casas J.M., Suzuki, L.A., Alexander, C.M. (Eds.). (2010). Handbook of multicultural counseling (3d ed.). Thousand Oaks, CA: Sage Publications.

Pope-Davis, D. B., Coleman, H. L. K., Liu, W. M., \& Toporek, R. L. (Eds.) (2003). Handbook of multicultural competencies: In counseling \& psychology. Thousand Oaks, CA: Sage Publications.

Portes, A. (2001). Introduction: the debates and significance of immigrant transnationalism. Global Networks, 1(3), 181-194. http://dx.doi.org/10.1111/1471-0374.00012 
Portes, A., Guarnizo, L. E., \& Landolt, P. (1999). The study of transnationalism: pitfalls and promise of an emergent research field. Ethnic and Racial Studies, 22(2), 217-237. http://dx.doi.org/10.1080/014198799329468

Portes, A., \& Rumbaut, R. G. (2001). Legacies: The story of the immigrant second generation. Berkeley, CA: University of California Press.

Portes, A., \& Rumbaut, R. (2006). Immigrant America: A portrait. Los Angeles, CA: University of California Press.

Portes, A., \& Zhou, M. (1993). The new second generation: Segmented assimilation and its variants. The Annals of the American Academy Of Political And Social Science, 530(1), 74-96. http://dx.doi.org/10.1177/0002716293530001006

Potter, J., \& Wetherell, M. (2001). Discourse theory and practice: A reader. Thousand Oaks, CA: Sage.

Pratto, F., Sidanius, J., Stallworth, L. M., \& Malle, B. F. (1994). Social dominance orientation: A personality variable predicting social and political attitudes. Journal of Personality and Social Psychology, 67, 741-763. http://dx.doi.org/10.1037//0022-3514.67.4.741

Pumariega, A. J., Rothe, E., \& Pumariega, J. A. B. (2005). Mental health of immigrants and refugees. Community Mental Health Journal, 41(5), 581-597. http://dx.doi.org/10.1007/s10597-005-6363-1

Rabin, N. (2008). Unseen prisoners: Women in immigration detention facilities in Arizona. Georgetown Immigration Law Journal, 23, 695-740.

Raval, H., \& Smith, J. A. (2003). Therapists' experiences of working with language interpreters. International Journal of Mental Health, 32, 6-31.

Riddick S. (1999). Linguistic issues. In E. Kramer, S. Ivey, \& Y. Ying (Eds.) Immigrant women's health: Problems and solutions. (pp. 35-43), San Francisco: Jossey-Bass.

Rigoni, I. (2012). Intersectionality and mediated cultural production in a globalized post-colonial world. Ethnic and Racial Studies, 35(5), 834-849. http://dx.doi.org/10.1080/01419870.2011.628035

Ross-Sheriff, F. \& Husain, A. (2004). South Asian Muslim children and families. In R. Fong. (Ed.), Culturally competent practice with immigrant and refugee children and families (pp. 163-182). New York: Guilford.

Roysircar, G. (2003). Understanding immigrants: Acculturation theory and research. In F. D. Harper, \& McFadden, J. (Eds.), Culture and counseling: New approaches. (pp. 164-185). San Francisco: Allyn \& Bacon.

Rogler, L. H. (1999). Methodological sources of cultural insensitivity in mental health research. American Psychologist, 54(6), 424-433.. http://dx.doi.org/10.1037//0003-066X.54.6.424 
Rohmann, A., Piontkowski, U., \& van Randenborgh, A. (2008). When attitudes do not fit: Discordance of acculturation attitudes as an antecedent of intergroup threat. Personality and Social Psychology Bulletin, 34(3), 337-352. http://dx.doi.org/10.1177/0146167207311197

Rudmin, F. W. (2003). Critical history of the acculturation psychology of assimilation, separation, integration, and marginalization. Review of General Psychology, 7(1), 3-37. http://dx.doi.org/10.1037//1089-2680.7.1.3

Rudmin, F. W. (2006). Debate in science: The case of acculturation. AnthroGlobe Journal. Retrieved on March 15, 2014 at http://munin.uit.no/bitstream/handle/10037/1996/article1.pdf?sequence=1.

Rudmin, F. (2009). Constructs, measurements and models of acculturation and acculturative stress. International Journal of Intercultural Relations, 33(2), 106-123. http://dx.doi.org/10.1016/j.ijintrel.2008.12.001

Salgado de Snyder, V. N. (1987). Factors associated with acculturative stress and depressive symptomatology among married Mexican immigrant women. Psychology of Women Quarterly. Special Issue: Hispanic women and mental health, 11, 475-488.

Sam, D. L., Vedder, P., Ward, C., \& Hoarenczyk, G. (2006). Psychological and sociocultural adaptation of immigrant youth. In J. W. Berry, J. S. Phinney, D. L. Sam, \& P. Vedder. (Eds.), Immigrant youth in cultural transition: Acculturation, identity and adaptation across national contexts (pp. 117-141). London: Lawrence Erlbaum.

Schiller, N. G., Basch, L., \& Blanc, C. S. (1995). From immigrant to transmigrant: Theorizing transnational migration. Anthropological Quarterly, 48-63. http://dx.doi.org/10.2307/3317464

Schwartz, S. J., \& Zamboanga, B. L. (2008). Testing Berry's model of acculturation: A confirmatory latent class approach. Cultural Diversity and Ethnic Minority Psychology, 14(4), 275.

Schwartz, S. J., Unger, J. B., Zamboanga, B. L., \& Szapocznik, J. (2010). Rethinking the concept of acculturation: Implications for theory and research. American Psychologist, 65(4), 237-251. http://dx.doi.org/10.1037/a0019330

Serdarevic, M., \& Chronister, K. M. (2005). Research with immigrant populations: The application of an ecological framework to mental health research with immigrant populations. The International Journal of Mental Health Promotion, 7(2), 24-34. http://dx.doi.org/10.1080/14623730.2005.9721864

Shahani, A. (2010). A stronger movement for immigrant rights. Immigrant Justice, March/April. Retrived from http://www.resistinc.org/newsletters/articles/stronger-movementimmigrant-rights. 
Sherif, M., Harvey, O. J., White, B. J., Hood, W. R., \& Sherif, C. W. (1961). Intergroup cooperation and competition: The Robbers Cave experiment. Norman, OK: University Book Exchange.

Sirojudin, S. (2009). Economic theories of emigration. Journal of Human Behavior in the Social Environment, 19, 702-712. http://dx.doi.org/10.1080/10911350902910880

Smith, J. P. \& Edmonston, B. (1997). The new Americans: Economic, demographic, and fiscal effects of immigration. Washington, D. C.: National Academy Press.

Sorensen, M., \& Krahn, H. (1996). Attitudes toward immigrants: A test of two theories. Alberta Journal of Educational Research, 42, 3-18.

Stephan, W. G., Boniecki, K.A., Ybarra, O., Bettencourt, A., Ervin, K. S., Jackson, L. A., McNatt, P. S., \& Renfro, C. L. (2002). The role of threats in the racial attitudes of Blacks and White. Personality and Social Psychology Bulletin, 28, 1242-1254.

http://dx.doi.org/10.1177/01461672022812009

Stephan, W. G., Renfro, C. L., Esses, V. M., Stephan, C. W., \& Martin, T. (2005). The effects of feeling threatened on attitudes toward immigrants. International Journal of Intercultural Relations, 29, 1-19. http://dx.doi.org/10.1016/j.ijintrel.2005.04.011

Stephan, W. G., \& Stephan, C. W. (2000). An integrated threat theory of prejudice. In S. Oskamp (Ed.), Claremont symposium on applied social psychology (pp. 23-46). Hillsdale, NJ: Erlbaum.

Stephan, W. G., Ybarra, O., \& Bachman, G. (1999). Prejudice toward immigrants: An integrated threat theory. Journal of Applied Social Psychology, 29, 2221-2237.

Suárez-Orozco, C., \& Carhill, A. (2008). Afterword: New directions in research with immigrant families and their children. New directions for child and adolescent development, 2008(121), 87-104. http://dx.doi.org/10.1002/cd.224

Suárez-Orozco, C., \& Suárez-Orozco, M. (1995). Transformations: Immigration, family life, and achievement motivation among Latino adolescents. Palo Alto, CA: Stanford University Press.

Sue, D. W. (1978). Eliminating cultural oppression in counseling: Toward a general theory. Journal of Counseling Psychology, 25(5), 419-428. http://dx.doi.org/10.1037//0022$\underline{0167.25 .5 .419}$

Sue, D. W., \& Sue, D. (1999). Counseling the culturally different: Theory and practice. New York: John Wiley.

Suzuki, L. A., \& Ponterotto, J. G. (Eds.). (2008). Handbook of multicultural assessment: Clinical, psychological, and educational applications. San Francisco: Jossey-Bass. 
Swinnen, S. G. H. A., \& Selten, J. P. (2007). Mood disorders and migration. The British Journal of Psychiatry, 190(1), 6-10.

Szapocznik, J. Ă., \& Kurtines, W. M. (1989). Breakthroughs in family therapy with drug abusing and problem youth. Springer Publishing Co.

Takeuchi, D. T., Alegria, M., Jackson, J. S., \& Williams, D. R. (2007). Immigration and mental health: diverse findings in Asian, black, and Latino populations. American Journal of Public Health, 97(1), 11-12. http://dx.doi.org/10.2105/AJPH.2006.103911

Toy, V. S. (April 28, 2002). Immigrant issues sprout like the daisies. The New York Times, Late Edition, Section 14LI, page 1, column 1.

Unger, J. B., Cruz, T. B., Rohrbach, L. A., Ribisl, K. M., Baezconde-Garbanti, L., Chen, X., Trinidad, D. R., et al. (2000). English language use as a risk factor for smoking initiation among Hispanic and Asian American adolescents: Evidence for mediation by tobaccorelated beliefs and social norms. Health Psychology, 19(5), 403-410. http://dx.doi.org/10.1037//0278-6133.19.5.403

Unger, J. B., Gallaher, P., Shakib, S., Ritt-Olson, A., Palmer, P. H., \& Johnson, C. A. (2002). The AHIMSA Acculturation Scale. The Journal of Early Adolescence, 22(3), 225-251.

van de Vijver, F., \& Tanzer, N. K. (2004). Bias and equivalence in cross-cultural assessment: An overview. Revue européenne de psychologie appliquée, 54(2), 119-135.

Vera, E. M., \& Speight, S. L. (2003). Multicultural competence, social justice, and counseling psychology: Expanding our roles. The Counseling Psychologist, 31(3), 253-272. http://dx.doi.org/10.1177/0011000003031003001

Vertovec, S. (1999). Conceiving and researching transnationalism. Ethnic and Racial Studies, 22(2), 447-462. http://dx.doi.org/10.1080/014198799329558

Watkins, M. (2007). Psyches and cities of hospitality in an era of forced migration: The shadows of slavery and conquest on the "immigration" debate. Spring, 78, 177-201.

Watkins, M. (2009). Restorative Practices in Small Group and Individual Work. In G. Nelson \& I. Prelliltensky (Eds.), Community psychology, 2nd edition (pp. 219-236). NY: Palgrave Macmillan.

Watkins, M. (2011). The shame of forcibly displacing Others: $9 / 11$ and the criminalization of immigration. American Philosophical Association Newsletter on Asian and Asian American Philosophers and Philosophies, 10, 2.

Watkins, M. (2012). Notes from a visit to several Zapatista Communities: Toward practices of nomadic identity and hybridity. Psychological Studies, 57(1), 1-8. http://dx.doi.org/10.1007/s12646-011-0113-y

Watkins, M., \& Shulman, H. (2008). Toward psychologies of liberation. Basingstoke, UK: Palgrave Macmillan. 
Weiland, M.L., Weis, J., Palmer, T., Goodson, M. Loth, S., Omer, F., Adeline, A., Krucker, K., Edens, K., \& Sia, I.G. (2012). Physical activity and nutrition among immigrant and refugee women: A Community-Based Participatory Research approach. Women's Health Issues, 22, 225-232.

Williams, C.L. \& Berry, J.W. (1991). Primary prevention of acculturative stress among refugees: An application of psychological theories and practice. American Psychologist, 46, 632641. http://dx.doi.org/10.1037//0003-066X.46.6.632

Wills, M. (2010). Psychological research and immigration policy. Journal of Social Issues, 66(4), 825-836. http://dx.doi.org/10.1111/j.1540-4560.2010.01677.x

Yakushko, O. (2009). Human trafficking: A Review for mental health professionals. International Journal for the Advancement of Counselling, 31, 158-167, doi: 10.1007/s10447-0099075-3.

Yakushko, O. (2009). Xenophobia: Understanding the roots and consequences of negative attitudes towards immigrants. The Counseling Psychologist, 37, 36-66. http://dx.doi.org/10.1177/0011000008316034

Yeh, C. J., Arora, A.K., Inose, M., Okubo, Y., Li, R., H., \& Greene, P. The cultural adjustment and mental health of Japanese Immigrant Youth. Adolescence, 38, 481-500.

Yu, E. S. H. (1985). Studying Vietnamese refugees: Methodological lessons in transcultural research. In T. C. Owan (Ed.), Southeast Asian mental health: Treatment, prevention, services, training and research. DHHS Publication No. ADM 85-1399. Washington, DC: U. S. Government Printing Office, pp. 517-541.

Zárate, M. A., \& Quezada, S. A. (2011). Future directions in research regarding attitudes toward immigrants. Analyses of Social Issues and Public Policy, 12, 160-166.

doi: 10.1111/j.1530-2415.2011.01270.x

Author bios:

Oksana Yakushko is a Chair and Core faculty in the clinical psychology department at the Pacifica Graduate Institute. Her scholarly interests have focused on varied aspects of the immigrant experience, including gendered adaptation, xenophobia, irregular migration (i.e., human trafficking), and approaches in clinical work and research with recent immigrants.

Melissa Morgan Consoli is an Associate Professor in the Counseling, Clinical and School Psychology Department at the University of California Santa Barbara. Her research is in the areas of resilience and thriving with Latino/a and immigrant populations. She teaches courses related to multicultural issues at the graduate and undergraduate levels. 
Journal for Social Action in Counseling and Psychology

Volume 6, Number 1, Summer 2014 